\title{
MAINTENANCE ISSUES OF THE VACUUM SEWER SYSTEM
}

\author{
Dino Obradović ${ }^{1, *}$, Marija Šperac ${ }^{1}$ and Saša Marenjak ${ }^{1}$ \\ ${ }^{1}$ Josip Juraj Strossmayer University of Osijek, Faculty of Civil Engineering and Architecture Osijek, Vladimira \\ Preloga 3, 31000 Osijek, Croatia,
}

*E-mail of corresponding author: dobradovic@gfos.hr

\begin{abstract}
A sewer system is an indispensable part of every settlement which contributes to the protection of the environment and people. There are many types of sewer systems. In addition to the standard sewer systems (mixed, separated, etc.), there are the alternative, non-standard systems, and one of them is a vacuum sewer system. In order for a sewer system to function correctly and to perform its tasks successfully, it needs to be maintained properly and regularly. Generally speaking, maintenance is considered to be a series of activities performed in order to achieve that constructed buildings allow an adequate use and functionality for the purpose they were designed for. Considering these systems are relatively new and still rarely used, there is no general practice or rules for use and maintenance of the same, and, most importantly, there is no user experience or people responsible for managing the work and maintenance. The paper will present the general characteristics and parts of vacuum sewer systems. Maintenance recommendations will be given, and maintenance costs specified making reference to the literature available to the authors.
\end{abstract}

Keywords: sewer system, maintenance, costs, vacuum sewer system

\begin{tabular}{c}
\hline Received: $18.06 .2019 . /$ Accepted: 06.11.2019. \\
Published online: 09.12 .2019$. \\
\hline
\end{tabular}

Professional paper

\section{INTRODUCTION}

Proper functioning of the sewer system is very important. The sewer system carries wastewater away from family houses, buildings, factories, as well as streets, into the wastewater treatment plants, which is a prerequisite of indispensable public hygiene. Because of that reason, the maintenance of wastewater system and wastewater pipes is of great importance (Obradović 2017; Obradović 2018b; Obradović et al. 2019) and a serious attention should be given to the maintenance (Šperac et al. 2012). The sewer system consists of pipelines, conduits, pumping stations, force mains, and all other facilities used to collect wastewater from individual residential, industrial, and commercial sources and convey it to the treatment facilities (KCNRK 2018) Generally, maintenance can be defined as the process of implementing the necessary activities to keep a building, all its parts, system or equipment to the specified operable condition and to preserve the value and purpose of buildings, systems and equipment (Obradović \& Marenjak 2017). Urbanization is becoming more and more evident, and there is a growing need for sewer maintenance and its renovation, using as little work on the terrain surface as possible (Obradović 2018a).

In the light of all the aforementioned considerations, the importance of a proper maintenance of the sewer system, as well as a more cost-effective utilization of money for design, maintenance, reconstruction and eventually the replacement of the sewer system and its components is clear. Moreover, not every type of terrain is suitable for any type of a sewer system. In order to try to solve some of the problems mentioned (and ultimately, each issue comes down to money), among other things, the invention of a vacuum sewer has been made as an alternative sewer system with a forced flow. The main reasons for the realization of such sewer systems were the requirements for a fully sealed sewer system, the rationalization of the quantity of the embedded material, the reduction of the work required during the sewer system construction and the efforts made to reduce the negative impacts on the environment during construction and exploitation (Šanta \& Fabry 2016; Hrskanović 2016). In many countries, this system has been widely used (Elawwad 2015), even in our neighbouring countries, such as: Hungary, Slovenia, Romania, Serbia, Germany, etc. In the Republic of Croatia, the vacuum sewer system was built in Županja and in one part of the town of Sisak. Relatively very few towns in the Republic of Croatia have such a system and there is little existing knowledge about the system and the way it is operated and maintained.

The sections of this article are structured as follows. Section 2 is intended to show brief history, technology of vacuum sewer system, advantages and disadvantages. Maintenance of vacuum sewer system and maintenance costs are given in Section 3. Section 4 gives brief discussion about dealt topic and provides some conclusions at the end of the paper. 


\section{VACUUM SEWER SYSTEM}

\subsection{History of vacuum sewer system}

Concepts of vacuum sewer system appeared already by the end of the 19th century (Tang et al. 2013), when technological developments allowed engineers to construct devices to pump sewage (Miszta-Kruk 2016). It is not entirely clear who can be named the inventor of vacuum sewer system and exact year of invention. A Dutch engineer and former Captain in the US army Charles Thieme Liernur, invented pneumatic system in 1868 (somewhere dated 1886) (Liernur 1892; Scott 1975; Petrešin \& Nekrep 2008; Redivac Limited 2014; Gikas 2017) where sewers were laid at uniform depth regardless of gradient and sewage was drawn through cast-iron pipes under half an atmosphere of vacuum (Read 2004). The Pneumatic System was first put in operation in 1871 in two districts in Amsterdam (Scott 1975). As can be seen from Figure 1 Liernur's system was used to collect sewage from domestic houses and consisted of an underground storage tank into which the effluent was received via iron pipes under gravity flow (Redivac Limited 2014).

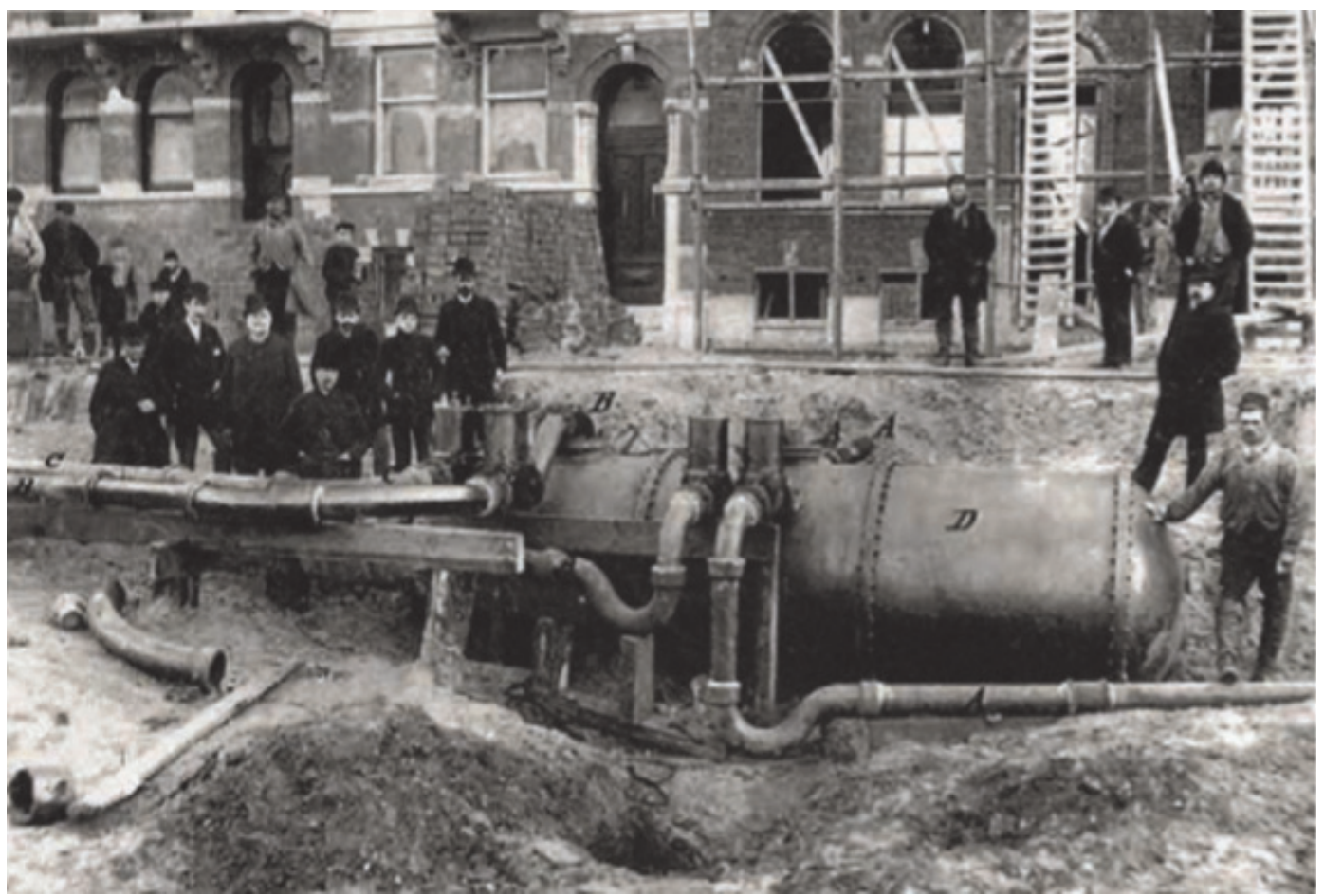

Figure 1. Vacuum sewer system in Amsterdam (Redivac Limited 2014; Schluff 2013)

By other authors (Lemarquand 1887; Miszta-Kruk 2016; Shafiqul Islam 2017; Gikas 2017) the first vacuum wastewater collection system was patented in 1888 in the United States by Adrian LeMarquand. And, at the end, by the third group of authors (Averill \& Heinke 1974; Read 2004; WEF 2007; Schluff 2013; Miszta-Kruk 2016) the first vacuum sewer system was patented in Sweden by Joel Liljendahl and was originally called the Liljendahl Vacuum Sewage System. In fact, Liljendahl continued to develop the vacuum sewerage system and tested it in the residential district in the north of Stockholm. It was employed first in 1959.

\subsection{Technology of vacuum sewer system}

The term vacuum sewer system has been widely used for simplification reasons and marketing purposes. Technically "vacuum" is not the correct term (for using in name "vacuum sewer system") since a vacuum is a void space free of any matter. Vacuum sewer system operates under negative pressure compared to the atmospheric pressure (Mohr 2016). However, because the term "vacuum sewer" is already established and common it will be used in this paper. The fundamental principle of the vacuum sewer system is the transport of wastewater by air pressure rather than by the gravity - induced flow of water. Vacuum sewer systems have two distinct advantages over conventional gravity systems: the vacuum system can function using much less water than gravity systems, and wastewater transport is not restricted to following hydraulic grade lines (Averill \& Heinke 1974).

Although there are several types and methods of its construction, each of these vacuum sewer systems operates on the same principle. Figure 2 shows the typical layout of a vacuum sewer system. 


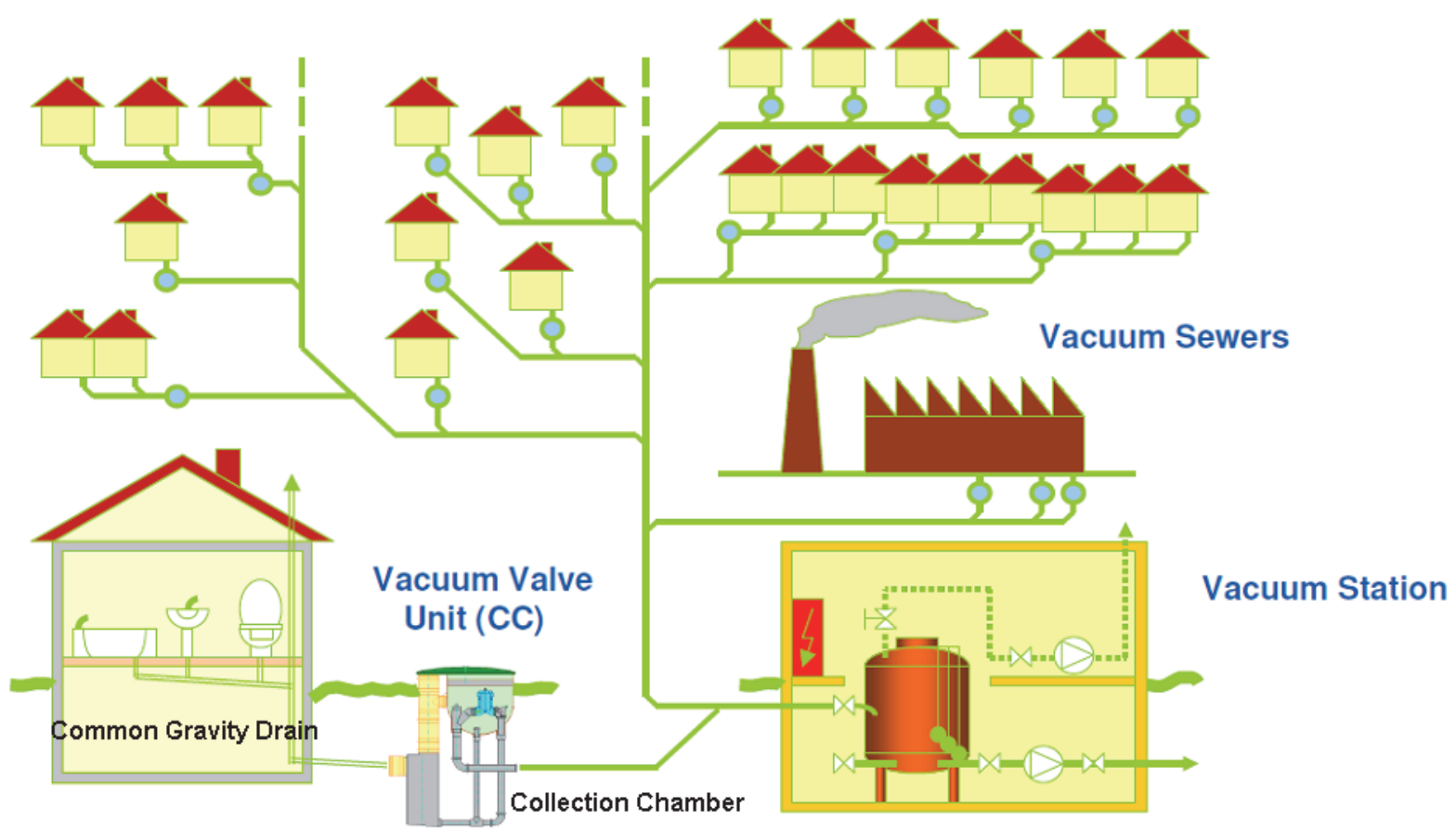

Figure 2. Overview of a typical vacuum sewer system with the vacuum valve unit, vacuum mains and the central vacuum station (Bilfinger Berger - Roediger 2007; Bilfinger Berger 2011; Becket 2017; Mohr et al, 2016; Stauffer \& Spuhler 2018; Mohr et al. 2018)

The vacuum in the vacuum sewer system is drawn by one or more vacuum pumps located in a central pumping station. There are no electrical components at the individual connections to the system (at the home) (Pipeline 1996; Aquate 2019). The wastewater that accumulates at the building level flows into the closely located collection chamber via a gravity line (Beckett, 2017). When the wastewater in the collection chamber reaches a certain level, a sensor prompts a pneumatic valve to open, and the entire plug of wastewater is violently sucked into the lines by the vacuum in the sewer main. The valve stays open a few seconds to also allow some air to be sucked in after the wastewater (Pipeline 1996). The amount of air that enters with the sewage is controlled by the length of time that the valve remains open. When the vacuum valves close, atmospheric pressure is restored inside the valve pit (Buchanan et al. 2010). As a standard practice, the necessary sub pressure (lower pressure than atmospheric) for operation of the vacuum system normally in range of 60 to 70 $\mathrm{kPa}$ ( 0.6 to 0.7 bars) or 40 to $30 \mathrm{kPa}$ absolute pressures. This pressure should be maintained by vacuum pumps (Shafiqul Islam 2017; Beckett 2017; Ciobotici et al. 2014; Panfil et al. 2013).

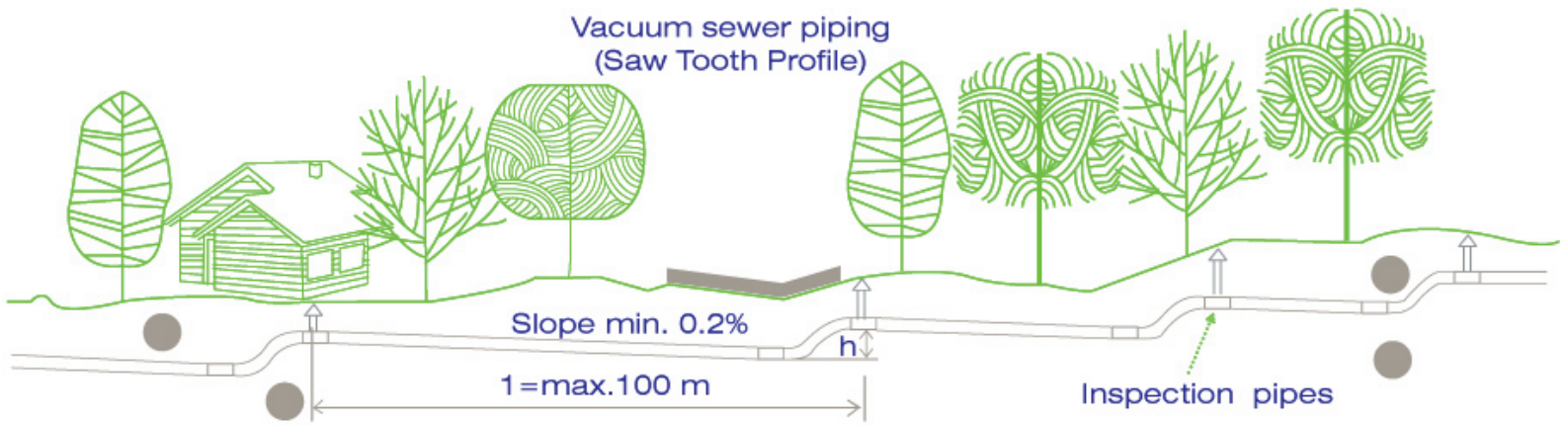

Figure 3. Saw-tooth profile (UW Tech 2019)

For vacuum sewer networks a saw-tooth pipe profile design is required (Bilfinger Berger 2012) (Figure 3). It means that the sewer line is composed of "lifts" and positive slopes towards the vacuum station. On the positive slopes the sewage is moved by gravity and on the negative slopes the sewage is moved by the differential pressure behind and in front of the sewage slug. The purpose of the saw-tooth-profile is to keep the trench depth shallow (1.0 to $1.2 \mathrm{~m}$ ), to transport the sewage uphill and to prevent the pipes from becoming sealed by keeping an open passage way on top of the sewer (WEF 2007; Mäkinen 2016). 


\subsection{Advantages and disadvantages of vacuum sewer system}

Many characteristics of vacuum sewer system can lead to benefits over other sewer systems. However, despite its flexibility a vacuum sewer system does not give a solution to every problem. In Table 1 are given advantages and disadvantages (please note this is partly subjective) of vacuum sewer system compared to other sewer system and technologies (Mohr et al. 2016).

Table 1. Summary of advantages and disadvantages of vacuum sewer system (Elawwad et al. 2014; Mohr et al. 2016; Ljubisavljević \& Obrenović 2010; Bilfinger Berger - Roediger 2007; Bilfinger Berger 2011; WEF 2007; UW Tech 2019; Gibbs 2016; Ma et al. 2015)

\begin{tabular}{|c|c|}
\hline Advantages & Disadvantages \\
\hline Small pipes diameter (90 to $250 \mathrm{~mm}$ ) & High energy consumption \\
\hline Shallow and narrow trenches ( 1.0 to $1.20 \mathrm{~m})$ & Additional cost for vacuum valves and vacuum stations \\
\hline No exfiltration in vacuum systems & Expert design is needed \\
\hline Better in flat areas (saw tooth profile) & Needs energy to maintain vacuum \\
\hline Minimum potential for blockage $(\mathrm{v}=6 \mathrm{~m} / \mathrm{s})$ & Network length is limited \\
\hline Shorter construction period & Skilled operators are required - training necessary \\
\hline $\begin{array}{l}\text { Less water is needed for transport to centralized } \\
\text { treatment facility }\end{array}$ & $\begin{array}{l}\text { Design guidelines and operation and maintenance are } \\
\text { not well known in developing countries }\end{array}$ \\
\hline No manholes are required & Number of system providers limited \\
\hline Fault detection is quick & Faults at individual valves can affect the entire systems \\
\hline $\begin{array}{l}\text { Installation in the same trench as water supply lines } \\
\text { possible }\end{array}$ & System components not quickly available everywhere \\
\hline \multicolumn{2}{|l|}{ Applicable in water protection zones } \\
\hline \multicolumn{2}{|l|}{$\begin{array}{c}\text { No infiltration of stormwater or groundwater due to } \\
\text { tight system }\end{array}$} \\
\hline \multicolumn{2}{|l|}{$\begin{array}{l}\text { Minimum maintenance at vacuum valves and } \\
\text { collection chambers }\end{array}$} \\
\hline \multicolumn{2}{|l|}{$\begin{array}{c}\text { Only one source of power, at the vacuum station, is } \\
\text { required }\end{array}$} \\
\hline \multicolumn{2}{|l|}{ Can be used in very narrow streets } \\
\hline \multicolumn{2}{|l|}{$\begin{array}{l}\text { Flexible pipeline construction independent from } \\
\text { topography }\end{array}$} \\
\hline \multicolumn{2}{|l|}{$\begin{array}{l}\text { Field changes can easily be made as unforeseen } \\
\text { underground obstacles can be avoided by going over, } \\
\text { under, or around them }\end{array}$} \\
\hline \multicolumn{2}{|l|}{$\begin{array}{l}\text { Minimum impact to the environment from } \\
\text { construction }\end{array}$} \\
\hline \multicolumn{2}{|l|}{$\begin{array}{c}\text { Vacuum sewer systems are the only systems allowed } \\
\text { to be installed in ecologically sensitive areas and } \\
\text { drinking water protection zones }\end{array}$} \\
\hline \multicolumn{2}{|l|}{ Little impact on local traffic } \\
\hline No dependence on external circumstances & \\
\hline $\begin{array}{l}\text { Earthquake proof, no rat trouble, no animals are } \\
\text { caught in the sewer net }\end{array}$ & \\
\hline
\end{tabular}




\subsection{Maintenance of vacuum sewer system}

A long-term and trouble-free operation of the sewer system requires a suitable design and its execution, but also properly performed preventive maintenance and repairs of the property. These periodically repeated activities (Table 2) are crucial for the sustainability and adequate service life of the sewer system (Mazák et al. 2017).

Table 2. Maintenance tasks and their frequencies (Mohr et al. 2016; Mäkinen 2016; Buchanan et al. 2010)

\begin{tabular}{|c|c|}
\hline Frequency & Maintenance Tasks \\
\hline Daily & $\begin{array}{l}\text { General inspection at the station } \\
\text { Visually check gauges/ charts } \\
\text { Record all pump run times } \\
\text { Check oil level in vacuum pump sight glass } \\
\text { Check alarms at the control cabinet } \\
\text { Fill out daily equipment check-up log book } \\
\text { Check alarm dialer function }\end{array}$ \\
\hline Weekly & $\begin{array}{l}\text { Exercise generator (if applicable) } \\
\text { Check vacuum system for leaks with manometer and record findings } \\
\text { Check oil level } \\
\text { Check for unusual noises } \\
\text { Check vacuum pump exhaust filter gauge } \\
\text { Visually/audibly check vacuum station operation }\end{array}$ \\
\hline Monthly & $\begin{array}{l}\text { Change oil and oil filters (depends on } \\
\text { manufacturer's recommendations) } \\
\text { Remove and clean inlet filters on vacuum pumps } \\
\text { Test all alarm systems } \\
\text { Check all motor couplings and adjust (if needed) } \\
\text { Clean all sight glasses } \\
\text { Exercise all shut off valves (vacuum station) } \\
\text { Check appearance of station (cleanliness and accessibility) } \\
\text { Check biofilter (humidity, odours, appearance) } \\
\text { Check sump for proper valve cycling } \\
\text { Check vacuum sensor (absolute pressure) }\end{array}$ \\
\hline $\begin{array}{l}\text { Semi-annually } \\
\text { to annually }\end{array}$ & $\begin{array}{l}\text { Conduct external leak test on all vacuum valves } \\
\text { Check electrical connections at the station } \\
\text { Check tank for deposits and remove them } \\
\text { Check alarm signals of the vacuum pumps } \\
\text { Check pump motors and couplings (wear, misalignment, deterioration, } \\
\text { overheating) }\end{array}$ \\
\hline Every year & $\begin{array}{l}\text { Exercise division valves } \\
\text { Inspect vacuum and sewage pumps for wear } \\
\text { Visual inspection of all pits and valves } \\
\text { Check valve timing and adjust if needed } \\
\text { Check functionality of alarms } \\
\text { Change oil of vacuum pump } \\
\text { Change oil filter of vacuum pump } \\
\text { Check state of construction of the station (e.g. corrosion, structures, etc.) } \\
\text { Floating switch cleaning and testing }\end{array}$ \\
\hline Every 3 years & Rebuild controller (buffer tank valves only) \\
\hline Every 5 years & Rebuild controller (most valves) \\
\hline Every 15 to 25 years & Replace a vacuum station equipment \\
\hline
\end{tabular}

If the vacuum sewer system is properly designed and constructed, there are very few things that can deteriorate in the vacuum sewer channel. Proper coordination of components and their individual properties is crucial. It is imperative to determine the amount of wastewater and select the components according to the required capacities. This applies not only to vacuum and sewerage pump capacities but also to the diameter of the vacuum mains. Due to lower transport velocities vacuum mains which have a large pipe diameter are more prone to scaling and precipitation from compounds contained in the wastewater. This can affect the durability of 
the selected material and thus the life span (Mohr et al. 2016). As with any sewer system, pipe cracking may occur due to land subsidence or landslide resulting in the loss of vacuum in the system. This is revealed by means of an alarm generated by the control system signalling the - vacuum loss, with the exact location of the crack that can be located by opening and closing the segment valves in a logical sequence along the pipeline. Another potential problem is the excessive amount of water in the system. If the system maintenance records are kept (and they should be kept in order for the maintenance to be performed properly), periodic inspections will be required with regards to the identified problems and the parts of the sewer system that are prone to malfunctions.

Preventive inspections and repairs are shown in Table 2. The time periods for the replacement of deteriorated parts and the preventive inspections are determined by the equipment manufacturers. Preventive action approaches minimize the risk of failures before they emerge. The availability of components needs to be checked and ensured when choosing a vacuum sewer system. In the event of system failure or material wear individual parts need to be available to ensure quick recovery of the sewer function. Therefore, sufficient stock and longterm material supply need to be assured (Mohr et al. 2016).

Emergency maintenance is mainly related to improper vacuum valve operation. The cause of this is usually a low vacuum level in the system or some other water in the system with the valves in the open position during the failure. This results in a vacuum loss because the system is open to the atmospheric pressure. If the inlet valve breaks in the open position, the monitoring system will detect the malfunction and alert the personnel responsible for the system operation and maintenance (Hrskanović 2016).

Operation and maintenance costs can vary significantly on how well the system is designed and how repair of the system failures is managed. Electricity and personnel costs are the major cost components (Mohr et al. 2016; Beckett 2017). However, material costs are also important but usually much lower than the electricity and personnel costs. In a comparative study on vacuum sewers in Germany electricity consumption of vacuum sewers was found to be in 15 to $30 \mathrm{kWh} /$ person/year or 0.2 to $0.4 \mathrm{kWh} /$ connection/day (Mohr et al. 2016). Table 3 provides cost estimation (and/or by experience) for the materials, installation, and maintenance of a vacuum sewer system.

Table 3. Approximate costs of materials, installation and maintenance of a vacuum sewer system (Schluff 2013; Buchanan et al. 2010)

\begin{tabular}{cc}
\hline Component & Approximate cost [in EUR] \\
\hline $\begin{array}{c}\text { Pipe costs depending of the } \\
\text { diameter }\end{array}$ & 10 to $50 \mathrm{EUR} / \mathrm{m}$ \\
\hline $\begin{array}{c}\text { Domestic connection, incl. control } \\
\text { and supervision plant }\end{array}$ & 3,000 \\
\hline Pump station, ready to be operated & 350,000 \\
\hline $\begin{array}{c}\text { Annual operation and maintenance } \\
\text { (for 100 vacuum pits) }\end{array}$ & 72,920 to 109,400 \\
\hline Annual electricity & 8,500 to 12,500 \\
\hline
\end{tabular}

The vacuum sewer system is not very widespread in the Republic of Croatia. One part of the town of Županja has it (Komunalac Županja 2016), as well as the suburban village of Galdovo - near the town of Sisak (Grad Sisak 2008; Sisački vodovod 2019).

It exists in some other towns or its construction is being considered, but to a lesser extent. The following section of the paper presents the vacuum sewer maintenance costs according to available data and research (Hrskanović 2016). A vacuum system maintenance comes down to maintaining a vacuum station, constituting the largest part of the costs. The sewage pipeline of the vacuum system does not require cleaning, except in cases of clogging, which is extremely rare, since the wastewater flow rates in the vacuum sewer system are very high and the vacuum pipeline is considered to be self-cleansing. Table 4 shows the electricity cost of the energy requirement for one vacuum station. Vacuum stations use one vacuum pump and one sewage pump, and both have a spare one in case of failure or service.

It is important to emphasize that a sewage system may consist of multiple vacuum stations (and usually it does), but the tables below show the maintenance costs of a single pumping station or costs per one unit. From all of the aforementioned, it is not a problem to calculate costs for, for example, a vacuum sewer system consisting of five vacuum stations. All the costs are expressed in monetary units - Croatian Kunas (HRK) and Euros (EUR) according to the Croatian National Bank's exchange rate on October 23, 2019 (Croatian national bank 2019). 
Table 4. Electricity costs for a vacuum station (Hrskanović 2016, edited)

\begin{tabular}{ccccccc}
\hline Component & $\begin{array}{c}\text { Engine } \\
\text { power }\end{array}$ & $\begin{array}{c}\text { Hours a } \\
\text { day }\end{array}$ & $\begin{array}{c}\text { Days a } \\
\text { year }\end{array}$ & $\begin{array}{c}\text { Electricity } \\
\text { price } \\
\text { [HRK/kWh] }\end{array}$ & $\begin{array}{c}\text { Cost } \\
\text { [in HRK] }\end{array}$ & $\begin{array}{c}\text { Cost } \\
\text { [in EUR] }\end{array}$ \\
\hline Vacuum pump & 2.5 & 8 & 220 & 0.529 & $2,327.60$ & 313.10 \\
\hline Sewage pump & 0.4 & 8 & 220 & 0.529 & 372.42 & 50.10 \\
\hline
\end{tabular}

Vacuum stations should undergo routine daily and monthly inspections and annual cleaning. Labour costs for daily, weekly, monthly and annual inspections and checks are shown in Table 5. Moreover, the vacuum pump is dismantled and cleaned once a year, which is usually performed by the manufacturer or an authorized person and represents a significant portion of the annual maintenance costs, since this service is "external" and is paid separately by an external contractor. Table 6 shows the total cost of maintaining and operating a single vacuum station.

Table 5. Vacuum station inspection costs (Hrskanović 2016, edited)

\begin{tabular}{ccccccc}
\hline Task & Workers & $\begin{array}{c}\text { Hours a } \\
\text { day }\end{array}$ & $\begin{array}{c}\text { Days a } \\
\text { year }\end{array}$ & $\begin{array}{c}\text { Labor cost } \\
\text { [HRK/h] }\end{array}$ & $\begin{array}{c}\text { Total cost } \\
\text { [in HRK] }\end{array}$ & $\begin{array}{c}\text { Total cost } \\
\text { [in EUR] }\end{array}$ \\
\hline Inspection & 1 & 0.5 & 365 & 60.00 & 10,950 & $1,472.96$ \\
\hline Pump replacement & 1 & 0.5 & 12 & 60.00 & 360.00 & 48.43 \\
\hline Maintenance & 1 & 2 & 1 & 60.00 & 120.00 & 16.14 \\
\hline Cleaning & - & - & 1 & - & 35,000 & $4,708.10$ \\
\hline
\end{tabular}

Table 6. Total cost of maintaining and operating a single vacuum station (Hrskanović 2016, edited)

\begin{tabular}{ccc}
\hline Item & Costs [in HRK] & Costs [in EUR] \\
\hline Electricity cost of the vacuum pump & $2,327.60$ & 313.10 \\
\hline Electricity cost of the sewage pump & 372.42 & 50.10 \\
\hline Inspection & 10,950 & $1,472.96$ \\
\hline Pump replacement & 360.00 & 48.43 \\
\hline Maintenance & 120.00 & 16.14 \\
\hline Cleaning & 35,000 & $4,708.10$ \\
\hline Repair of vacuum pump & $6,762.50$ & 909.69 \\
\hline TOTAL & $55,892.52$ & $7,518.51$ \\
\hline
\end{tabular}

\section{CONCLUSION}

Vacuum sewer system is considered an alternative wastewater collection system. Vacuum sewer systems have many advantages, such as water savings, shallow and narrow trenches, smaller pipe diameter, good sanitation conditions, flexible pipeline construction independent from topography, shorter construction period, etc. However, the investment and operational costs, as well as the applicability can vary significantly between regions and the need for them to be assessed under local conditions. Vacuum sewer systems show less negative environmental and social impacts than the conventional system. Under appropriate conditions and with a proper maintenance, the vacuum sewer system does not present any additional requirements with respect to the inevitable operating costs and the necessary resources of the operator. As with any building, a timely and proper maintenance is very important. Proper coordination of components and their individual properties is crucial. Preventive action approaches minimize the risk of a failure before it occurs, and because of this, a preventive maintenance should be performed on time and must be carefully planned.

Although there are a lot of aforementioned advantages and benefits of the vacuum sewer system, there is some unease and scepticism because of the unfamiliarity with the technology from all the groups including users, operators, planners and construction companies. As the infrastructure is becoming obsolete, the importance of circular concepts and circular economy is becoming vital, including water reuse, nutrient recovery etc. The vacuum sewer systems can be a viable alternative for the improvement or further development of the sewer system. Moreover, considering the increasing efforts being made to tackle water-related issues, the economic and social sustainability of the vacuum sewer system should be considered as a potential alternative to the sewer system in near future. 


\section{REFERENCES}

Aquate. (2019) Flovac Vacuum Sewer Systems, Available via DIALOG http://www.aquate.co.nz/?page id=49/ Cited May 13, 2019.

Averill WD, Heinke WG (1974) Vacuum Sewer Systems and their Possible Canadian Applications, Can. J. Civ. Eng., 1(50):50-61, DOI: https://doi.org/10.1139/174-004

Beckett M (2017) Characterization of vacuum sewer systems in Germany and the potential as leapfrogging technology in the Global South, Thesis, Faculty of Environment and Natural Resources, Albert-LudwigsUniversity of Freiburg

Bilfinger Berger (2007) ROEDIGER®, Roevac Vacuum Sewer Systems, PP_Sewer_2007_e_International Division_Ver_2.1/Cited May 9, 2019.

Bilfinger Berger. (2011) ROEDIGER ${ }^{-}$VACUUM, Vacuum Sewer Systems An Economic Alternative to Conventional Gravity Sewer Systems, Available via DIALOG http://www.sawea.org/pdf/SAWEA_RoeVac.pdf Cited May 20, 2019.

Bilfinger Berger. (2012) ROEDIGER ${ }^{\circledR}$ VACUUM, Vacuum Sewer Systems Construction Manual, Version:

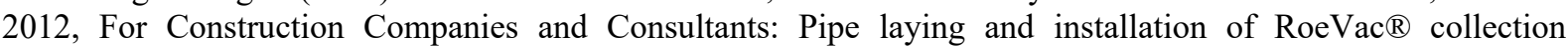
chambers and valves

Buchanan J, Deal N, Lindbo D, Hanson A, Gustafson D, Miles R (2010) Performance \& Cost of Decentralized Unit Processes, Fact Sheet C4: Vacuum Sewer Systems, Water Environment Research Foundation, Alexandria

Ciobotici Terryn IC, Lazar I, Nedeff V, Lazar G (2014) Conventional vs. Vacuum Sewerage System in Rural Areas - An Economic and Environmental Approach, Environ. Eng. Manag. J, 13(8):1847-1859, http://www.eemj.icpm.tuiasi.ro/pdfs/vol13/no8/Full/1_160 Terryn_14.pdf

Croatian national bank: Exchange rate list number: 204, Available via DIALOG https://www.hnb.hr/corefunctions/monetary-policy/exchange-rate-list/exchange-rate-list Cited October 23, 2019.

Elawwad A, Ragab M, Abdel-Halim H (2014) Vacuum Sewerage System in Developing Regions and the Impact on Environmental Management. In: Proceedings of the 4th International Conference on Environmental Pollution and Remediation, Prague, Czech Republic, 82-1 - 82-8.

Elawwad A, Ragab M, Abdel-Halim H (2015) An economical, environmental, and social comparison between vacuum and gravity sewers in decentralized sanitation systems, with Egypt as a case study, Jour. Water Sanit. Hyg. Develop., 5(4):614-619, DOI: https://doi.org/10.2166/washdev.2015.099

Gibbs S (2016) Keeping Ocean Shores Clean: Coastal Town Relies on Vacuum Sewers, Informed Infrastructure, Available via DIALOG https://informedinfrastructure.com/27066/keeping-ocean-shores-cleancoastal-town-relies-on-vacuum-sewers Cited May 6, 2019.

Gikas P, Ranieri E, Sougioultzis D, Farazaki M, Tchobanoglous G (2017) Alternative collection systems for decentralized wastewater management: an overview and case study of the vacuum collection system in Eretria town, Greece, Water Pract. Tech., 12(3):604-618, DOI: https://doi.org/10.2166/wpt.2017.050

Grad Sisak (2016) Galdovo dobilo najmoderniju kanalizaciju u Hrvatskoj, Available via DIALOG https://sisak.hr/galdovo-dobilo-najmoderniju-kanalizaciju-u-hrvatskoj Cited October 23, 2019.

Hrskanović I (2016) Maintenance of drainage systems of urban settlements, master thesis, Josip Juraj Strossmayer University of Osijek, Faculty of Civil Engineering Osijek, Osijek (in Croatian)

Kingdom of Cambodia Nation Religion King (KCNRK), Ministry of Public Works and Transport General

Directorate of Public Works Sewerage Management and Construction Department (2018) Wastewater System Operation and Maintenance Guideline, Phnom Penh

Komunalac Županja, https://komunalac-zu.hr/index.php/prikljucak Cited October 22, 2019.

LeMarquand A (1887) Sewerage or Drainage of Houses, Towns, or Districts, and Apparatus Therefor, Patent No. 170,079, France, Available via DIALOG http://www.sewerhistory.org/images/aus/aus4/1888 377681.pdf Cited May 09, 2019.

Liernur TC (1892) Pneumatic sewerage system, United States Patent Office, Patent No. 482,439, Available via DIALOG http://www.sewerhistory.org/images/aus/aus4/1892_482439.pdf Cited May 10, 2019.

Ljubisavljević D, Obrenović M (2010) Non-standard Sewage Systems: Vacuum and Pressure Sewage, VODOPRIVREDA, 42(246-248):237-244. (in Serbian)

Ma XC, Xue X, González-Mejía A, Garland J, Cashdollar J (2015) Sustainable Water Systems for the City of Tomorrow - A Conceptual Framework, Sustainability, 7(9):12071-12105, DOI: https://doi.org/10.3390/su70912071

Mazák J, Dvorský T, Václavík V, Zajac R, Hluštík P (2017) The proposal of recommendations for the operation of vacuum sewerage, IOP Conf. Ser.: Earth Environ. Sci., 92(012042), https://iopscience.iop.org/article/10.1088/1755-1315/92/1/012042/pdf

Mäkinen M (2016) Operation of Vacuum Sewer System - Case Ondangwa, Namibia, Master of Science Thesis, Tampere University of Technology 
Miszta-Kruk K (2016) Reliability and failure rate analysis of pressure, vacuum and gravity sewer systems based on operating data, Engineering Failure Analysis, 61:37-45, DOI: https://doi.org/10.1016/j.engfailanal.2015.07.034

Mohr M, Beckett M, Schließmann U, Erlbeck R, Trosse R (2018) Vacuum sewerage systems - a solution for fast growing cities in developing countries? Water Pract. Tech., 13(1):157-163, DOI: https://doi.org/10.2166/wpt.2018.028

Mohr M, Iden J, Beckett M (2016) Guideline: Vacuum sewer systems, Fraunhofer-Institut für Grenzflächenund Bioverfahrenstechnik IGB, Stuttgart

Obradović D (2018a) A short review: Techniques for trenchless sewer rehabilitation, in Conference proceedings: 10th International Scientific Conference on Civil and Environmental Engineering: YOUNG SCIENTIST 2018, Tatranská Lomnica, Slovakia

Obradović D (2018b) Preventing malfunctions by growth prevention and removal of tree roots in sewer pipes, VODOPRIVREDA, 50(291-293):165-173. (in Croatian), http://www.vodoprivreda.net/wpcontent/uploads/2019/01/16-Dino-Obradovi\%C4\%87_R.pdf

Obradović D (2017): The impact of tree root systems on wastewater pipes, in Conference proceedings: Peti skup mladih istraživača iz područja građevinarstva i srodnih tehničkih znanosti Zajednički temelji '17, ZT 2017, Zagreb, pp. 65-71, DOI: https://doi.org/10.5592/CO/ZT.2017.03

Obradović D, Marenjak S (2017) The role of maintenance in the life cycle of a building, In: Conference Proceedings: 26th International Scientific and Professional Conference "Organization and Maintenance Technology" - OTO 2017, Osijek, Croatia, pp. 61-67. (in Croatian)

Obradović D, Šperac M, Marenjak S (2019) Possibilities of using expert methods for sewer system maintenance optimization, Građevinar, 71(9):769-779., DOI: https://doi.org/10.14256/JCE.2589.2018

Panfil C, Mirel I, Szigyarto I, Isacu M (2013) Technical, economical, social and ecological characteristics of vacuum sewage system, Environ. Eng. Manag. J., 12(5):1017-1022., DOI: 10.30638/eemj.2013.125

Petrešin E, Nekrep MP (2008) H3) Design and construction of the vacuum sewerage system, in Proceedings of the 34 International Symposium on CIB WO62 Water Supply and Drainage for Buildings, Hong Kong, China

Pipeline (1996) Small Community Wastewater Issues Explained to the Public: Alternative Sewers: A Good Option for Many Communities, National Small Flows Clearinghouse, Pipeline, 7(4):1-8, http://www.nesc.wvu.edu/pdf/WW/publications/pipline/PL_FA96.pdf

Read FG (2004) Vacuum Sewerage, Chapter 16. In: Read FG (ed) Sewers, Replacement and New Construction, Elsevier, pp. 327-338, DOI: https://doi.org/10.1016/B978-0-7506-5083-0.X5000-2

Redivac Limited (2014) An introduction to Redivac Vacuum Technology, United Kingdom, Available via DIALOG http:/www.hifraser.com.au/wp-content/uploads/2015/05/140711-Redivac-The-Vacuum-WayBrochure-2014.pdf Cited March 06, 2019.

Schluff R (2013) Vacuum sewerage system, PhD Thesis, University Politehnica of Bucharest, Doctoral school of power engineering, Bucharest, Romania

Scott A (1876) The Liernur system at Amsterdam, Journal of the Society of Arts, May 26, pp. 671.

Shafiqul Islam M (2017) Comparative evaluation of vacuum sewer and gravity sewer systems, Int J Syst Assur Eng Manag, 8(1):37-53, DOI: https://doi.org/10.1007/s13198-016-0518-Z

Sisački vodovod, Odvodnja, Available via DIALOG https://sisackivodovod.hr/djelatnosti/odvodnja/ Cited October 22, 2019.

Stauffer, B., Spuhler, D. (2018): Vacuum Sewers, SSWM University Course, Available via DIALOG https://sswm.info/sswm-university-course/module-2-centralised-and-decentralised-systems-water-andsanitation/further/vacuum-sewers Cited March 06, 2019.

Šanta Č, Fabry G (2016) Vakumski sistem kanalisanja upotrebljenih voda, in Conference Proceedings 14. Savetovanje SDHI, Fruška Gora, Srbija, 342-353 (in Serbian)

Šperac M, Moser V, Stvorić T (2012) Maintenance of the sewerage system using GIS, Electronic Journal of the Faculty of Civil Engineering Osijek-e-GFOS, 5:86-94., DOI: http://dx.doi.org/10.13167/2012.5.8 (in Croatian)

Tang J, Li M, Wang B (2013) An Introduction to Vacuum Sewerage System and its Applications in China, Advanced Materials Research, 610-613:2467-2471, DOI: https://doi.org/10.4028/www.scientific.net/AMR.610$\underline{613.2467}$

UW Tech (2019) Vacuum Sewerage System, UW Tech GmbH, Available via DIALOG http://uwtechgmbh.de/sewerage-system Cited March 06, 2019.

Water Environment Federation (WEF): Alexandria, Virginia (2007) Vacuum Sewers 101, PDHengineer Course No. C-4028 